\title{
No sex please, we're dentists
}

\author{
Stephen Hancocks OBE \\ Editor-in-Chief
}

The BDJ Upfront section includes editorials, letters, news, book reviews and interviews. Please direct your correspondence to the News Editor,

Adrian O'Dowd at BDJNews@nature.com. Press releases or articles may be edited, and should include a colour photograph if possible.

$\mathrm{T}$ here was, or is, a sense of Britishness that shuns the idea that sex even exists. That it is a vague necessity but is otherwise slightly shady, messy, inconvenient and 'not very nice', especially in terms of discussion. Indeed it was often joked that before the supposed sexual revolution of the 1960s oral sex meant talking about it. To help throw it into a perspective a stage farce opened in London's West End in 1971 called No Sex Please, We're British. It was universally panned by the critics but then proceeded to run for more than 16 years clocking up over 6,700 performances. To my credit, or discredit, I didn't ever see it but my theory then, as now, is that audiences flocked to the theatre precisely because of the implied prurience of the title. And indeed, apparently the plot revolved around 'Scandinavian pornography' - those Swedes and Danes, how sexually liberated and wayward in a school-boyish, giggling behind the hands, titillating way.

Much has changed since then but somethings have not as a paper in this issue indicates by reporting on the stigmatisation still experienced at the dentist by some people living with HIV. ${ }^{1}$

Of course we now know that HIV is not transmitted only by sexual contact but the sentiment remains as does the lingering association with gay men (or more correctly and accurately now, men who have sex with men since it is not an 'exclusively' gay activity - another myth that the No Sex Please, We're British mentality would perpetuate as fact). However, the stigma remains as, it seems, does the memory of the arms-length early days of grappling with the outbreak of AIDS. Yet how can that be since it was in the mid-1980s? Practitioners, even those newly qualifying at that time, would now be in their late fifties at least. At that time HIV was a mystery and was an understandably worrying development. How was it spread? How virulent? How to prevent, contain and stop it? HIV positive patients were treated by clinicians attired in space-suit type protection which now seems ridiculous - but it was a not totally unreasonable reaction, we thought we were doing what was best. We now know full well that universal cross-infection control negates such concerns and that billions of dental treatments have been completed without any untoward consequences. So why the stigma?

Is it the lingering cultural tail of 'not very nice-ness'? Is there something that we are not admitting to ourselves as professionals and if there is shouldn't we talk about it? In this Journal in recent times we have published items that have sexual activity as a relevant central issue. One described an art-science project at King's College about oral sex and included the word cunnilingus. Interestingly, practitioners in the behavioural sciences. We are taught to be surgeons, with a very slight nod towards being oral physicians (but not really, that might go away if we ignore it a bit), and yet the management and ultimately the prevention of both of the major diseases that we treat in humanity worldwide, caries and periodontal disease, relies on motivation and behavioural change. We're not very good at that because, honestly, it was not what we signed up for. That is why thirty-plus years after the advent of AIDS we still have the collective memory and fear of hands-offness that creates stigma and concern. Honestly, we have to get over ourselves and importantly we have to be good examples to our other team members in the same regard.

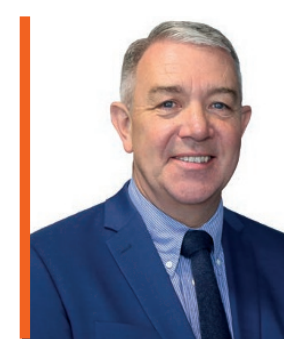

\section{'Thirty-plus years after the advent of AIDS we still have the collective memory of hands-offness that creates stigma and concern...'}

I received three emails from separate readers all expressing their amazement that they never expected to read 'that' in the BDJ. Really? Why? Another paper described dental students' readiness to explore patients' history in relation to the human papilloma virus (HPV) in the light of its implications in oral cancer. 'What', the research insight writer queried, 'would be a clinician's reaction be to a male patient asking if it was safe to give his boyfriend a blow job?' We live in the real world, we care for real people and we have to accept that this may mean that we cannot hide in our preferred comfort zone when we are fulfilling a professional role.

What I think also underlies this tendency is the flaw that we are not trained as
Their education and understanding of these issues may be even less well developed than ours. We need to show the way.

Perhaps significantly No Sex Please, We're British transferred to New York's Broadway and ran for only 16 performances before closing ignominiously. I suspect that it was down to the American sense of humour rather than any puritanism but I also wonder if the authors of the paper in this issue were to run a similar survey in the USA whether the results would be similar... and in Scandinavia? What do you think? DOI: 10.1038/sj.bdj.2018.591

1. Okala S, Doughty J, Watt R G et al. The People Living with HIV STIGMASurvey UK 2015: Stigmatising experiences and dental care. Br Dent J 2018; 225: 143-150. 